\title{
The Influence of Climate Organization and Individual Characteristics on the Employees' Performance of Regional Office of Sulawesi, Maluku, and Its Alignments Muhammad Ardiansyah, Sri Setya Handayani \\ Badan Penyelenggara Jaminan Sosial (BPJS), Guna Darma University, Jakarta Selatan, Indonesia
}

\begin{abstract}
Work productivity is the effective and efficient utilization of human resources, the accuracy or appropriateness of the use of methods or ways of working compared to the available tools and time, to achieve goals. The main measure is the completion of volumes and workload on time, using minimal human resources. Theoretically, many factors contribute to the productivity of employee work in an organization, the quality of both the external nature and the internal organizational environment. Every employee has different characteristics. This difference illustrates that each employee has different individual characteristics. Rivai (2011) (in Astri, 2015) states that "Individual characteristics are special traits, mental characteristics, morals or character possessed by someone who distinguishes it from others". This study aims to analyze and examine (1) To describe the organizational climate, individual character, and performance of employees of the BPJS Employment Office of the Sulawesi Maluku Regional Office and its Alignments; (2) To analyze the effect of organizational profiles, individual characteristics on the performance of BPJS Employment staff of the Sulawesi Maluku Regional Office and its Alignments. The survey was conducted on 203 employees of the Regional Office of the BPJS Employment Office of the Sulawesi Maluku Regional Office and their ranks were randomly selected. Data collected through observation, interviews, and questionnaires. Data were analyzed using descriptive analysis and PLS (Partial Least Square) analysis. The results showed that (1) Organizational Climate, Individual Character and Performance of Employees of BPJS Employees in the Sulawesi Maluku Regional Office and their ranks are classified as good; (2) Organizational climate and individual character significantly influence the performance of BPJS Employment staff of the Sulawesi Maluku Regional Office and its Alignments
\end{abstract}

Keywords : Organizational Climate, Individual Character, Employee Performance

\section{INTRODUCTION}

The low work productivity of employees in an organization, both public and non-public organizations, is still an actual problem to be studied. Work productivity is always directed at how to do or utilize something to reflect the principles of effectiveness and efficiency. It is said to be efficient when an internal processor resource is needed by an organization to produce one unit of output. Therefore efficiency can be measured as the ratio of output to input (Lubis, 2011). While something is said to be effective if the organization can fully achieve the targets set. Effectiveness is generally seen as the level of achievement of operative and operational objectives. Thus basically effectiveness is the level of achievement of organizational goals or objectives as determined (Sumaryadi, 2005). 
Work productivity is the effective and efficient utilization of human resources, the accuracy or appropriateness of the use of methods or ways of working compared to the available tools and time, to achieve goals. The main measure is the completion of volumes and workload on time, using minimal human resources.

In addition to individual characteristics, organizational climate is also an important factor in an organization. Organizational climate is something that is felt by the people in an organization. What is felt affects the behavior that will ultimately determine the level of productivity of their work. Employee work productivity is closely related to the existing structure, namely regarding the division of labor by following the existing part, the employee's responsibilities towards his duties either individually, in groups, or organizationally; communication created by superiors to subordinates; respect for human resources; rewards and sanctions applied. Employee work productivity in public organizations are not measurable materially or financially but can be seen in the completion of existing volumes and workloads, and timeliness in addition to the quality of the services they provide. Furthermore, the extent to which the task can be carried out according to the field of work by utilizing a variety of available resources including human resources so that goals can be achieved.

One that every organization wants to achieve is to be able to retain their best employees who always contribute to the organization. Employees as individuals in an organization are the most important part because they have a large role in determining the success of achieving organizational goals. As the most important organizational asset, the functions, and roles of employees are needed to maximize the performance, productivity, and effectiveness of the organization through efficient work methods that produce added value for the organization.

\section{Research purposes}

1. To describe the organizational climate, individual characteristics, and performance of BPJS Employees in the Sulawesi Maluku Regional Office and their Alignments.

2. To determine the effect of organizational climate and individual characteristics on the performance of BPJS Employment staff in the Sulawesi Maluku Regional Office and its Alignments.

\section{Literature Review}

\section{Organizational Climate}

Climate or climate comes from the Greek language that is inclined, this word not only gives a limited meaning to physical things such as temperature or pressure but also has a psychological meaning that the people in the organization describe the internal environment of the organization. The organizational climate was first used by Kurt Lewin in the 1930s, which used the term psychological climate, then the term organizational climate was used by R. Tagiuri and G. Litwin. According to Tagiuri and Litwin in Wirawan (2007) that "Organizational the climate is a relatively ongoing quality of the internal environment experienced by members of the organization, influencing the behavior of each member".

Stringer (2002) in Wirawan (2007) defines that organizational climate as a collection and environmental patterns that determine the emergence of motivation and focus on perceptions that make sense or can be assessed so that it has a direct influence on the performance of organizational members. Davis and Hewstrom (1995: 23) state: 
"Organizational climate is the environment in which the employees of an organization does their work. Climate surrounds and influences everything that works in organizations so that climate is said to be a dynamic concept. According to the above definition, we can see that climate is a dynamic concept that influences the overall organization in the environment where the organization is active in the context of achieving its goals.

Gibson, Ivancevich, and Donelly (2011) state: "Organizational climate is a set of environmental conditions that are felt directly or indirectly by employees." Gibson, Ivancevich, and Donelly describe organizational climate as several conditions or conditions in a series that are directly or indirectly, knowingly or unknowingly, affects employees/employees. Luthans (2011) and Simamora (2004) state that organizational climate is the internal environment or organizational psychology. Organizational climate influences human resources practices and policies accepted by members of the organization. Please note that each organization will have a different organizational climate. The diversity of jobs designed within the organization or the nature of the individuals that exist will illustrate these differences. All organizations naturally have a strategy in managing human resources. An open organizational climate encourages employees to express their interests and dissatisfaction without fear of retaliation and attention. Such dissatisfaction can be handled positively and wisely. A climate of openness, however, is only created if all members have a high level of confidence and believe in the fairness of action. Organizational climate is important to be created because it is a person's perception of what is given by the organization and is used as a basis for determining the behavior of future members. Climate is determined by how well members are directed, built and valued by organizations.
From the various meanings above, a conclusion can be drawn that the organizational climate is a state of internal or psychological quality within the institutional organization which is perceived by every employee and assumed to influence employee attitudes and behavior.

Kelneer (1990) in Hendry (2015) mentions six organizational climate dimensions as follows:

a. Flexibility conformity. Flexibility and conformity are organizational conditions that provide freedom of action for employees and make adjustments to the tasks given. This relates to the rules set by the organization, existing policies, and procedures. Acceptance of new ideas is a supporting value in developing a conducive organizational climate for the achievement of organizational goals.

b. Responsibility This relates to employees' feelings about the implementation of organizational tasks that are carried out with a sense of responsibility for the results achieved because they are involved in the ongoing process.

c. Standards. Employees' feelings about the condition of the organization where management pays attention to the implementation of tasks properly, goals that have been determined as well as tolerance of mistakes or things that are not appropriate or not good.

d. Reward. This relates to employees' feelings about appreciation and recognition for good work.

e. Clarity. Associated with employees' feelings that they know what is expected of them is related to work, the role and goals of the organization.

f. Commitment Team. Relating to employees' feelings about their pride in having an organization and their willingness to do more when needed. 
Also besides, Denison (1990) divides organizational climate into seven elements, which is:

a. organization of work (organization of work), namely the extent to which work methods in the organization can connect individual tasks with organizational goals.

b. communication flow, which is how information flows within the body of an organization, both vertically within the organizational hierarchy and laterally across organizations.

c. The emphasis of people (emphasis on human resources), namely how the attention of the organization in the welfare and development of its employees.

d. Decision-making practices, namely the extent to which organizational decisions involving the people to be influenced are made at a reasonable level and are based on a wide variety of information.

e. influence and control (influence and supervision) that is the extent of the influence of superiors on the people underneath.

f. absence of bureaucracy (absence of obstacles in the bureaucracy or smooth administration) Namely the absence of administrative obstacles in the internal functioning of the organization. Thus everything goes according to the rules.

g. coordination (coordination), namely the existence of coordination, cooperation, and resolution of problems between work units in the organization.

From the dimensions presented by the experts, it appears that there are different views about the elements that are supporting the organizational climate. Each has advantages and disadvantages. In this study, the dimension of Denison was chosen as a reference in the independent variable.

\section{Individual Characteristics}

Theoretically, many factors contribute to the productivity the employee work in an organization, the quality of both the external nature and the internal organizational environment. Every employee has different characteristics. This difference illustrates that each employee has different individual characteristics. Rivai (2011) (in Astri, 2015) states that "Individual characteristics are special traits, mental characteristics, morals or character possessed by someone who distinguishes it from others". Someone's characteristics greatly affect one's life patterns, characteristics can be seen from several perspectives including age, sex, and level of education of a person, besides that someone's seriousness in maintaining his health greatly affects the quality of his life both inactivity, rest, or psychologically (Astri, 2015 ). This difference illustrates that individual characteristics are not the same between an employee and other employees. Attitudes and abilities possessed by each employee will reflect employee behavior at work, so attitudes and abilities possessed by each employee must reflect positive behavior, such as having a high sense of responsibility, respecting superiors and coworkers, being able to get along well with colleagues work, have an attitude of confidence, be patient, and are not easily dependent on others.

Each person is a unique personality thanks to his background, individual characteristics, needs and way of looking at the world and other individuals. According to Ivancevich et.al. (in Nahrisah, 2013) Individual characteristics are "People who see things differently will behave differently, people who have different attitudes will respond differently to commands, people who have different personalities interact differently with superiors, coworkers, and subordinates ". Robbins (2008), argues that variables 
at the individual level include biographical characteristics, abilities, personality, and learning. While the biographical characteristics include: age, sex, marital status, number of dependents and years of service with an organization of the employees themselves. Ability characteristics include intellectual and physical abilities, personal characteristics include personality.

According to Maslow (in Normansyah, 2010) describes the characteristics of individuals who are defined as self-actualizing people about: (a) The ability to perceive people and events accurately; (b) The ability to free oneself from the chaos of life; (c) Task problem orientation; (d) The ability to obtain personal satisfaction from personal development in doing something valuable; (e) Capacity to love and experience life in a very profound way; Interest in what goals they are working on; (f) High creativity at work. Thoha in Setianingsih (2011) mentions matters relating to individual characteristics, that individuals bring into the organizational structure, abilities, personal beliefs, expectations of needs and past experiences. These are all characteristics possessed by individuals and these characteristics will enter a new environment, namely the organization.

In an organization individual differences are common. Different individuals will have different views, goals, needs, and abilities. These differences will be brought into the world of work so that with the differences like these individuals, it often causes individual behavior to differ from one another, even though they are placed in the same work environment.

Based on the opinions above, it can be interpreted that individual characteristics are a picture of a person's condition that is carried in the organizational structure, into the world of work, and tends to always develop and influence in carrying out work activities.

Ivancevich et.al. (in Nahrisah, 2013) revealed 4 individual characteristics, namely: (a) ability, (b) personality, (c) perception, and (d) attitude. Meanwhile, according to Sopiah (2008) revealed 4 individual characteristics that distinguish between one another, namely: (a) biographical characteristics, age, sex, marital status, and years of service, (b) personality, (c) perception, and (d) attitude.

\section{Employee Performance}

In an organization, both private sector (private sector) and government organization (public sector), employee performance or work performance is a very important aspect in the organization's efforts to achieve its goals. Organizational performance can not be separated from the performance of employees in carrying out their duties and work. Thus, the progress or failure of an organization is largely determined by the role and quality of its employees.

Etymologically, performance comes from the word performance. Performance comes from the word to perform that has several entries (i.e., i) doing, (2) fulfilling or running something, (3) carrying out a responsibility, (4) doing something that is expected by someone. From this input it can be interpreted, performance is to do an activity and perfect the work by following its responsibilities so that it can achieve the results as expected.

Mangkunegara (2010) said that: Performance is the result of the quality and quantity of work achieved by someone in carrying out their functions by following the responsibilities given to him. Rivai and Basri in Emmyah (2009) argued that: Performance is the result or overall level of success of a person 
during a certain period in carrying out the task compared with the possible outcomes, such as work standards, targets or targets or criteria determined in advance and agreed upon.

According to Wibowo (2014) in Nadira (2015) performance is the implementation of the plans that have been prepared. Implementation of performance is carried out by human resources who have the ability, competence, motivation, and interests. How an organization values and treats its human resources will influence its attitudes and behavior in carrying outperformance.

Looking at the various descriptions of employee performance above, it can be concluded that basically performance always leads to the potential for work that is obtained from certain job functions or certain activities during a certain period time.

Sutrisno (2013) revealed that performance appraisal or performance is a formal process to periodically review and evaluate one's work performance. Performance evaluation according to Mangkunegara (2010) is an assessment carried out systematically to find out the results of employee work and organizational performance. Performance evaluation or performance appraisal is a suggestion to improve those who are not doing their job properly in the organization. Performance appraisal according to Hasibuan (2011) is "assessing the risk of real work outcomes with quality and quantity standards produced by each employee".

The purpose of performance evaluation or performance appraisal according to Mangkunegara (2012) is to improve or improve organizational performance through improving the performance of organizational human resources. Employee performance appraisal can be done from 4 (four) sources, namely:

\section{Self-Assessment}

Self-assessment is the process by which individuals evaluate their performance, using a structured approach, as a basis for talks with their leaders in evaluation meetings. The structure of self-assessment is usually given a self-assessment form that is filled in by individuals before the evaluation meeting.

2. Rating by Subordinates

Evaluation by subordinates provides the possibility for subordinates to judge or comment on certain aspects of the performance of their leaders. The aim is to make leaders more aware of issues relating to their performance from the perspective of their subordinates.

3. Peer assessment

Peer assessment is an evaluation made by fellow team members or colleagues who are on the same network. The usual practice is to ask individuals to provide an assessment to colleagues or other networks. This is more likely to be behavioral.

4. Assessment by Multi Assessment

The advantage of getting different points of view in performance evaluation, especially from leaders, has led to greater attention to valuations with various sources of appraisers who can add value to the evaluation of traditional leaders/subordinates. This can include using upward and by peers in addition to evaluations by leaders. Theoretically, much can be said about this approach, but in practice, the system will be in trouble to be overreacted in addition to being vulnerable to all the shortcomings that people consider to be weaknesses of both the upward assessment process or peer assessment. Consequently, there is little evidence of interest in this multi-rater evaluation. 
Dessler (1995) mentions that there are dimensions of individual work performance, such as quality and quantity that need to be assessed, dimensions of work performance should be based on behavior so that all assessments can be made with the objective and observable evidence. This illustrates that good or bad performance is not only determined from the quantitative level that can be produced by someone at work but also must be measured in terms of quality.

\section{RESEARCH METHODS}

The design used in this study is a Quantitative Research that is located with the research object used, namely Employees and employees in the regional office and branch offices of BPJS on the level of Sulawesi Maluku with a sample of 203 people. with the proportionate stratified random sampling technique. Data collection was carried out through a survey by distributing questionnaires. Analysis of the data used is descriptive analysis and PLS (Partial Least Square) analysis. The mathematical model of this study is stated as follows: 1

$\mathrm{KP}=\mathrm{b} 1 \mathrm{IO}+\varepsilon 1 \mathrm{Sub}-$ structure $(1)$

$\mathrm{KP}=\mathrm{b} 2 \mathrm{KI}+\varepsilon 2 \quad$ Sub-structure (2)

Information:

IO : Organizational Climate

KI : Individual Characteristics

$\mathrm{KP}=$ Employee Performance

b1 : Path coefficient of IO influence on KP

b2 : Path coefficient of the influence of IC on KP

$\varepsilon 1 \quad$ : Disturbance error

ع2 : Disturba

\section{Discussion}

1. Descriptive Analysis of Research Variables

a. Organizational Climate

Table 1. Distribution of Respondents' Answers to Organizational Climate Variables

\begin{tabular}{|c|c|c|c|c|c|c|c|c|c|c|c|c|}
\hline \multirow{3}{*}{ NO } & \multirow{3}{*}{ STATEMENT } & \multicolumn{10}{|c|}{ SCORE } & \multirow{3}{*}{$\begin{array}{l}\text { SCORE } \\
\text { TOTAL }\end{array}$} \\
\hline & & \multicolumn{2}{|c|}{1} & \multicolumn{2}{|c|}{2} & \multicolumn{2}{|c|}{3} & \multicolumn{2}{|c|}{4} & \multicolumn{2}{|c|}{5} & \\
\hline & & F & $\%$ & F & $\%$ & F & $\%$ & $\mathrm{~F}$ & $\%$ & F & $\%$ & \\
\hline IO1 & $\begin{array}{l}\text { Methods of work in organizations } \\
\text { can connect individual tasks with } \\
\text { organizational goals }\end{array}$ & 0 & $0,0 \%$ & 1 & $0,5 \%$ & 18 & $14,4 \%$ & 127 & $62,6 \%$ & 57 & $28,1 \%$ & 849 \\
\hline IO2 & $\begin{array}{l}\text { I can communicate openly with } \\
\text { colleagues }\end{array}$ & 0 & $0,0 \%$ & 1 & $0,5 \%$ & 6 & $4,8 \%$ & 96 & $47,3 \%$ & 100 & $49,3 \%$ & 904 \\
\hline IO3 & $\begin{array}{l}\text { I can communicate openly with } \\
\text { superiors }\end{array}$ & 0 & $0,0 \%$ & 2 & $1,0 \%$ & 19 & $15,2 \%$ & 106 & $52,2 \%$ & 76 & $37,4 \%$ & 865 \\
\hline IO4 & $\begin{array}{l}\text { I can express opinions (ideas or } \\
\text { suggestions) for organizations with }\end{array}$ & 2 & $1,0 \%$ & 3 & $1,5 \%$ & 31 & $24,8 \%$ & 116 & $57,1 \%$ & 51 & $25,1 \%$ & 820 \\
\hline IO5 & $\begin{array}{l}\text { The organization pays attention to } \\
\text { employee welfare }\end{array}$ & 1 & $0,5 \%$ & 4 & $2,0 \%$ & 12 & $9,6 \%$ & 89 & $43,8 \%$ & 97 & $47,8 \%$ & 886 \\
\hline IO6 & $\begin{array}{l}\text { The organization pays attention to } \\
\text { employee career development }\end{array}$ & 1 & $0,5 \%$ & 11 & $5,4 \%$ & 36 & $28,8 \%$ & 115 & $56,7 \%$ & 40 & $19,7 \%$ & 791 \\
\hline IO7 & $\begin{array}{l}\text { Organizations involve employees } \\
\text { in making decisions }\end{array}$ & 1 & $0,5 \%$ & 11 & $5,4 \%$ & 63 & $50,4 \%$ & 100 & $49,3 \%$ & 28 & $13,8 \%$ & 752 \\
\hline IO8 & $\begin{array}{l}\text { Leaders/superiors often provide } \\
\text { solutions to work problems }\end{array}$ & 2 & $1,0 \%$ & 1 & $0,5 \%$ & 37 & $29,6 \%$ & 116 & $57,1 \%$ & 47 & $23,2 \%$ & 814 \\
\hline
\end{tabular}




\begin{tabular}{|c|c|c|c|c|c|c|c|c|c|c|c|c|}
\hline IO9 & $\begin{array}{l}\text { The frequency of mentoring } \\
\text { leaders/superiors while doing } \\
\text { work is quite high. }\end{array}$ & 3 & $1,5 \%$ & 9 & $4,4 \%$ & 55 & $44,0 \%$ & 108 & $53,2 \%$ & 28 & $13,8 \%$ & 758 \\
\hline IO10 & $\begin{array}{l}\text { The attitude of the leader/superior } \\
\text { affects employee productivity }\end{array}$ & 0 & $0,0 \%$ & 1 & $0,5 \%$ & 10 & $8,0 \%$ & 92 & $45,3 \%$ & 100 & $49,3 \%$ & 900 \\
\hline IO11 & $\begin{array}{l}\text { There are no administrative } \\
\text { obstacles in the internal } \\
\text { functioning of the organization, } \\
\text { everything works according to the } \\
\text { rules }\end{array}$ & 0 & $0,0 \%$ & 8 & $3,9 \%$ & 35 & $28,0 \%$ & 126 & $62,1 \%$ & 34 & $16,7 \%$ & 795 \\
\hline IO12 & $\begin{array}{l}\text { coordination, cooperation, and } \\
\text { problem resolution among work } \\
\text { units in the organization run well }\end{array}$ & 1 & $0,5 \%$ & 5 & $2,5 \%$ & 27 & $21,6 \%$ & 124 & $61,1 \%$ & 46 & $22,7 \%$ & 818 \\
\hline
\end{tabular}

Source: Primary data processing results (January, 2019)

In table 1 it can be seen that the answers of respondents for points 1,2 and 3 the majority answered agree and strongly agree with the work methods in the organization, as well as the freedom of communication with colleagues and with direct superiors. In terms of expressing opinions (ideas or suggestions) for organizations freely reaching $57.1 \%$ of respondents gave positive answers, but not a few also gave answers hesitantly reaching $24.8 \%$. This indicates that some employees feel free to express opinions (ideas or suggestions) for the organization freely.

In points 5 and 6 , it can be seen that employees feel the organization is concerned about employee welfare by answering strongly agree by $47.8 \%$ and in the statement "the organization pays attention to employee career development" even though most agree but not a small number of employees who doubt this statement. This indicates there are still some employees who feel that the organization is not paying attention to their career development.

In point 7 , it can be seen that the majority of employees feel involved in decision making, where 49.3\% agree but not the least also answer hesitantly reaching $31 \%$ this is because most of the policies or rules come from the central office.

At points 8, 9, and 10 is an assessment of the leadership. Most respondents gave positive responses.
They agree that the attitude of the leader/superior influences the work productivity of employees, for that mentoring superiors and providing solutions to work problems must be considered by leaders/superiors.

The 11th Statement of Point "there are no administrative obstacles in the internal functioning of the organization, all goes according to the rules" of $62.1 \%$ of respondents agreed, but $17.2 \%$ chose a doubtful answer. This indicates there are still employees who sometimes find obstacles in the implementation of internal functions of the organization.

Almost the same as in Point 11, in Point 12 "coordination, cooperation and resolution of problems among work units in the organization went well" most respondents gave answers agreeing to reach $62.1 \%$, but there are still doubts about the statement. Organizations should pay attention to communication and coordination between work units to maintain harmony in the implementation of tasks.

Of the 12 statement points on organizational climate variables, the highest score on the item "I can communicate openly with colleagues" with a value of 904 points and the lowest score is on the item "Organization involves employees in decision making" with a value of 752 points. 


\section{b. Individual Characteristics}

Table 2

Distribution of Respondents' Answers To Individual Characteristics Variables

\begin{tabular}{|c|c|c|c|c|c|c|c|c|c|c|c|c|}
\hline \multirow{3}{*}{ NO } & \multirow{3}{*}{ STATEMENT } & \multicolumn{10}{|c|}{ SCORE } & \multirow{3}{*}{$\begin{array}{l}\text { SCORE } \\
\text { TOTAL }\end{array}$} \\
\hline & & \multicolumn{2}{|c|}{1} & \multicolumn{2}{|c|}{2} & \multicolumn{2}{|c|}{3} & \multicolumn{2}{|c|}{4} & \multicolumn{2}{|c|}{5} & \\
\hline & & F & $\%$ & F & $\%$ & $\mathrm{~F}$ & $\%$ & F & $\%$ & F & $\%$ & \\
\hline KI1 & $\begin{array}{l}\text { I was able to complete the task } \\
\text { given by the boss }\end{array}$ & 0 & $0,0 \%$ & 0 & $0,0 \%$ & 3 & $1,5 \%$ & 105 & $51,7 \%$ & 95 & $46,8 \%$ & 904 \\
\hline KI2 & $\begin{array}{l}\text { I have the ability to complete } \\
\text { work according to expertise } \\
\text { without the help of others. }\end{array}$ & 3 & $1,5 \%$ & 15 & $7,4 \%$ & 37 & $18,2 \%$ & 114 & $56,2 \%$ & 34 & $16,7 \%$ & 770 \\
\hline KI3 & $\begin{array}{l}\text { I have analytical skills according } \\
\text { to the work placement division }\end{array}$ & 0 & $0,0 \%$ & 1 & $0,5 \%$ & 20 & $9,9 \%$ & 131 & $64,5 \%$ & 51 & $25,1 \%$ & 841 \\
\hline KI4 & $\begin{array}{l}\text { I was able to provide a solution to } \\
\text { the completion of the work. }\end{array}$ & 0 & $0,0 \%$ & 0 & $0,0 \%$ & 7 & $3,4 \%$ & 130 & $64,0 \%$ & 66 & $32,5 \%$ & 871 \\
\hline KI5 & $\begin{array}{l}\text { I can to operate work-related } \\
\text { equipment. }\end{array}$ & 0 & $0,0 \%$ & 0 & $0,0 \%$ & 5 & $2,5 \%$ & 117 & $57,6 \%$ & 81 & $39,9 \%$ & 888 \\
\hline KI6 & $\begin{array}{l}\text { I am among those who easily } \\
\text { socialize with coworkers. }\end{array}$ & 0 & $0,0 \%$ & 0 & $0,0 \%$ & 6 & $3,0 \%$ & 113 & $55,7 \%$ & 84 & $41,4 \%$ & 890 \\
\hline KI7 & $\begin{array}{l}\text { I establish communication with } \\
\text { other work units in completing a } \\
\text { job. }\end{array}$ & 0 & $0,0 \%$ & 0 & $0,0 \%$ & 7 & $3,4 \%$ & 106 & $52,2 \%$ & 90 & $44,3 \%$ & 895 \\
\hline KI8 & $\begin{array}{l}\text { I collaborate with colleagues so } \\
\text { that the results are good. }\end{array}$ & 0 & $0,0 \%$ & 0 & $0,0 \%$ & 9 & $4,4 \%$ & 86 & $42,4 \%$ & 108 & $53,2 \%$ & 911 \\
\hline KI9 & My work is done responsibly. & 0 & $0,0 \%$ & 0 & $0,0 \%$ & 3 & $1,5 \%$ & 62 & $30,5 \%$ & 138 & $68,0 \%$ & 947 \\
\hline KI10 & I was able to work under pressure. & 2 & $1,0 \%$ & 5 & $2,5 \%$ & 27 & $13,3 \%$ & 116 & $57,1 \%$ & 53 & $26,1 \%$ & 822 \\
\hline KI11 & $\begin{array}{l}\text { I am not easily nervous, when } \\
\text { dealing with new things, } \\
\text { especially in new methods. }\end{array}$ & 0 & $0,0 \%$ & 3 & $1,5 \%$ & 27 & $13,3 \%$ & 124 & $61,1 \%$ & 49 & $24,1 \%$ & 828 \\
\hline KI12 & $\begin{array}{l}\text { I tend to be curious about new } \\
\text { things that are on the job. }\end{array}$ & 0 & $0,0 \%$ & 1 & $0,5 \%$ & 5 & $2,5 \%$ & 120 & $59,1 \%$ & 77 & $37,9 \%$ & 882 \\
\hline KI13 & $\begin{array}{l}\text { I am an open person when it } \\
\text { comes to new technology. }\end{array}$ & 0 & $0,0 \%$ & 0 & $0,0 \%$ & 4 & $2,0 \%$ & 116 & $57,1 \%$ & 83 & $40,9 \%$ & 891 \\
\hline KI14 & $\begin{array}{l}\text { My co-workers are the team to } \\
\text { complete the task. }\end{array}$ & 1 & $0,5 \%$ & 0 & $0,0 \%$ & 4 & $2,0 \%$ & 85 & $41,9 \%$ & 113 & $55,7 \%$ & 918 \\
\hline KI15 & $\begin{array}{l}\text { The leader always gives a good } \\
\text { example to his subordinates. }\end{array}$ & 1 & $0,5 \%$ & 3 & $1,5 \%$ & 33 & $16,3 \%$ & 90 & $44,3 \%$ & 6 & $3,0 \%$ & 496 \\
\hline KI16 & $\begin{array}{l}\text { For me the compatibility of work } \\
\text { with expertise is very necessary in } \\
\text { working. }\end{array}$ & 0 & $0,0 \%$ & 0 & $0,0 \%$ & 6 & $3,0 \%$ & 99 & $48,8 \%$ & 98 & $48,3 \%$ & 904 \\
\hline KI17 & I prioritize accuracy in working & 0 & $0,0 \%$ & 0 & $0,0 \%$ & 8 & $3,9 \%$ & 93 & $45,8 \%$ & 102 & $50,2 \%$ & 906 \\
\hline
\end{tabular}




\begin{tabular}{|c|c|c|c|c|c|c|c|c|c|c|c|c|}
\hline KI18 & $\begin{array}{l}\text { In making decisions I need data, to } \\
\text { be correct in making decisions }\end{array}$ & 0 & $0,0 \%$ & 0 & $0,0 \%$ & 3 & $1,5 \%$ & 82 & $40,4 \%$ & 118 & $58,1 \%$ & 927 \\
\hline KI19 & $\begin{array}{l}\text { I can make complex ideas easy to } \\
\text { understand by putting together a } \\
\text { meaningful explanation. }\end{array}$ & 0 & $0,0 \%$ & 1 & $0,5 \%$ & 16 & $7,9 \%$ & 136 & $67,0 \%$ & 50 & $24,6 \%$ & 844 \\
\hline KI20 & $\begin{array}{l}\text { I am responsive to every problem } \\
\text { that occurs at the office. }\end{array}$ & 0 & $0,0 \%$ & 0 & $0,0 \%$ & 15 & $7,4 \%$ & 125 & $61,6 \%$ & 63 & $31,0 \%$ & 860 \\
\hline KI21 & $\begin{array}{l}\text { I am happy when new employees } \\
\text { join the organization. }\end{array}$ & 0 & $0,0 \%$ & 0 & $0,0 \%$ & 5 & $2,5 \%$ & 107 & $52,7 \%$ & 91 & $44,8 \%$ & 898 \\
\hline KI22 & $\begin{array}{l}\text { I help new employees adapt to the } \\
\text { work environment. }\end{array}$ & 0 & $0,0 \%$ & 1 & $0,5 \%$ & 8 & $3,9 \%$ & 112 & $55,2 \%$ & 82 & $40,4 \%$ & 884 \\
\hline
\end{tabular}

Source: Primary data processing results (January, 2019)

In table 2 above is the respondent's answer to individual characteristic variables. The statements in Points 1 to 5 are statements for the dimensions of ability (ability to complete tasks, ability to analyze, ability to operate equipment). In this dimension, almost all respondents were able to complete the tasks given by superiors and were able to operate equipment related to their work. But there is still a doubtful response to the item statement "I can finish work according to expertise without the help of others." 37 people were hesitant and 15 people did not agree. This is normal, especially for new employees who are still adapting to their new jobs. In the ability to analyze dimension, there are still employees who doubt the ability to analyze according to the division of work placement by 20 people or $9.9 \%$ and provide solutions to the completion of work as many as 7 people or $3.4 \%$ but the majority still feel able to do so. The role of leadership to help direct and improve the quality of human resources is indeed very important to assist employees in developing their human resource capabilities.

Points 6 to 13 are statement items for the personality dimension (one's level of comfort in dealing with other individuals, individual's tendency to be obedient to other individuals, caution, emotional stability, and openness to new things). The majority of respondents gave positive answers or agreed to statements $6,7,8,9,12$ and 13 . This indicates that employees can socialize and communicate well with colleagues and other work units in completing their work responsibly. They also tend to be open to new things related to work. This provides positive energy for the organization to further enhance its performance targets going forward. What the organization must pay attention to is that employees are unable to work under pressure. This can be seen by the answers of respondents STS ( 2 people), TS ( 5 people), RR (27 people), $83.3 \%$ of employees who make sure they can work under pressure. Even though they are capable of completing work responsibly, they tend not to be able to work under pressure.

The statements in Points 14 to 17 are statements for the dimensions of perception (assessment of $\mathrm{co}^{-}$ workers, evaluation of leaders, assessment of work). In this dimension, the respondent gave a positive answer even though the Chairman always gave a good example to his subordinates, there were still those who gave a doubtful answer of $16.3 \%$. Some leaders should pay more attention to this with a more 
careful attitude or treat employees because the leader must provide a good example to his subordinates.

The last dimension is the attitude (conceptual thinking, level of satisfaction with work results and the behavior of old employees towards new employees) represented by the statements in Points 18 to 22. From the six Points statement, 3 of them (18, 21 , and 22) the majority of respondents answered agree. This shows that employees can think conceptually and old employees tend to be open to new employees both in welcoming and providing assistance adapting to the work environment), but around $7.9 \%$ of respondents tend to be still less responsive to any problems that occur at the office. It is important to note that some employees are still doubtful about their ability to make complex ideas easily understood by compiling a meaningful explanation. If an organization can minimize this, employees will be more effective and efficient in completing their tasks.

Of all the statement items above, the highest score on the statement item "My work is done responsibly." With a total score of 947 while the lowest score on the statement item "The leader always gives a good example to his subordinates." With a total score of 496.

\section{c. Employee Performance}

\section{Table 3}

Distribution of Respondents' Responses to Employee Performance Variables

\begin{tabular}{|c|c|c|c|c|c|c|c|c|c|c|c|c|}
\hline \multirow{3}{*}{ NO } & \multirow{3}{*}{ STATEMENT } & \multicolumn{10}{|c|}{ SCORE } & \multirow{3}{*}{$\begin{array}{l}\text { SCORE } \\
\text { TOTAL }\end{array}$} \\
\hline & & \multicolumn{2}{|c|}{1} & \multicolumn{2}{|c|}{2} & \multicolumn{2}{|c|}{3} & \multicolumn{2}{|c|}{4} & \multicolumn{2}{|c|}{5} & \\
\hline & & F & $\%$ & F & $\%$ & F & $\%$ & F & $\%$ & F & $\%$ & \\
\hline KP1 & $\begin{array}{l}\text { I always achieve the } \\
\text { performance targets that I set }\end{array}$ & 0 & $0,0 \%$ & 0 & $0,0 \%$ & 4 & $2,0 \%$ & 122 & $60,1 \%$ & 77 & $37,9 \%$ & 885 \\
\hline KP2 & $\begin{array}{l}\text { I work with teams to meet } \\
\text { organizational performance }\end{array}$ & 0 & $0,0 \%$ & 0 & $0,0 \%$ & 3 & $1,5 \%$ & 86 & $42,4 \%$ & 114 & $56,2 \%$ & 923 \\
\hline KP3 & $\begin{array}{l}\text { The results of my work are in } \\
\text { line with organizational } \\
\text { performance standards }\end{array}$ & 0 & $0,0 \%$ & 2 & $1,0 \%$ & 3 & $1,5 \%$ & 113 & $55,7 \%$ & 85 & $41,9 \%$ & 890 \\
\hline KP4 & $\begin{array}{l}\text { I am always thorough in } \\
\text { carrying out the work assigned }\end{array}$ & 0 & $0,0 \%$ & 0 & $0,0 \%$ & 7 & $3,4 \%$ & 114 & $56,2 \%$ & 82 & $40,4 \%$ & 887 \\
\hline KP5 & $\begin{array}{l}\text { The creative ideas that I provide } \\
\text { are always used/accepted }\end{array}$ & 0 & $0,0 \%$ & 2 & $1,0 \%$ & 41 & $20,2 \%$ & 126 & $62,1 \%$ & 34 & $16,7 \%$ & 801 \\
\hline KP6 & $\begin{array}{l}\text { Bosses rarely criticize the results } \\
\text { of my work }\end{array}$ & 4 & $2,0 \%$ & 12 & $5,9 \%$ & 48 & $23,6 \%$ & 105 & $51,7 \%$ & 34 & $16,7 \%$ & 762 \\
\hline KP7 & $\begin{array}{l}\text { I ask colleagues when there are } \\
\text { difficulties }\end{array}$ & 0 & $0,0 \%$ & 1 & $0,5 \%$ & 7 & $3,4 \%$ & 99 & $48,8 \%$ & 96 & $47,3 \%$ & 899 \\
\hline KP8 & $\begin{array}{l}\text { Creative ideas that I have are } \\
\text { difficult for others to imitate }\end{array}$ & 5 & $2,5 \%$ & 27 & $13,3 \%$ & 86 & $42,4 \%$ & 64 & $31,5 \%$ & 21 & $10,3 \%$ & 678 \\
\hline KP9 & $\begin{array}{l}\text { I was able to complete the task } \\
\text { by following the target }\end{array}$ & 0 & $0,0 \%$ & 0 & $0,0 \%$ & 7 & $3,4 \%$ & 114 & $56,2 \%$ & 82 & $40,4 \%$ & 887 \\
\hline KP10 & $\begin{array}{l}\text { Every time I was given a task, I } \\
\text { immediately did it without delay }\end{array}$ & 0 & $0,0 \%$ & 0 & $0,0 \%$ & 8 & $3,9 \%$ & 114 & $56,2 \%$ & 81 & $39,9 \%$ & 885 \\
\hline
\end{tabular}




\begin{tabular}{|c|c|c|c|c|c|c|c|c|c|c|c|c|}
\hline KP11 & $\begin{array}{l}\text { I can submit reports or work } \\
\text { results to superiors on time }\end{array}$ & 0 & $0,0 \%$ & 0 & $0,0 \%$ & 4 & $2,0 \%$ & 104 & $51,2 \%$ & 95 & $46,8 \%$ & 903 \\
\hline
\end{tabular}

Source: Primary data processing results (January, 2019)

In this employee performance variable, there are 11 statement points as described in table 4.6 which represent each of the 2 dimensions, namely quality, and quantity. Respondents' answers to these employee performance variables are quite diverse. Three statement points received a poor response from the respondents. This reflects that there are still aspects of employee performance appraisal that have not met the set indicators.

In Point 5 "Creative ideas that I give are always used/accepted" as many as 2 people answered disagree and 41 people or $20.2 \%$ who answered doubtfully. In Point 8 "Creative ideas that I have are difficult for others to imitate" as many as 5 people who answered strongly disagree, 27 people answered disagree, 86 people answered doubtfully. this shows around 58.1\% of respondents gave answers that reflect the performance of employees for this aspect is still relatively low. Most employees still lack innovation for creative ideas. Many things affect this, one of which is the role of leadership and regulations applied. The same thing happened to the statement in Point 6 "The boss rarely criticizes the results of my work" as many as 4 people or $2.5 \%$ answered disagree, as many as 12 people or $40.20 \%$ gave answers disagree and 48 people or $23.6 \%$ answered doubtfully. This is natural, criticism from the leadership will be a motivation for employees to complete the work by following the expected targets.

Points 9 to 11 show that employees have good performance in terms of quantity. They can complete tasks with targets and can complete work on time. Although there are still a handful of employees who doubt their ability in this matter.
Of all the statement items above, the highest score on the statement item "I worked with the team to meet the organization's performance." With a total score of 923 while the lowest score on the statement item "Creative ideas that I have difficult for others to imitate." total score of 678.

\section{Effect of Organizational Climate, Individual Characteristics, and Employee Performance}

The results of the analysis show that the organizational climate and individual character have a positive and significant influence on employee performance. This means that the better the quality of the organizational climate will affect the performance of employees in the labor BPJS in the Sulawesi Maluku Regional Office and its Alignment. After going through the stages of analysis starting from Validity Test and Questioner Reliability Test, Initial Outer Model Test, Model2 and Model 3, Test Validity and Reliability of Constructive Modeling and Structural Model Analysis (Inner Model Test) followed by Hypothesis Testing using Bootstrap shows the results as shown in the figure and the table below.

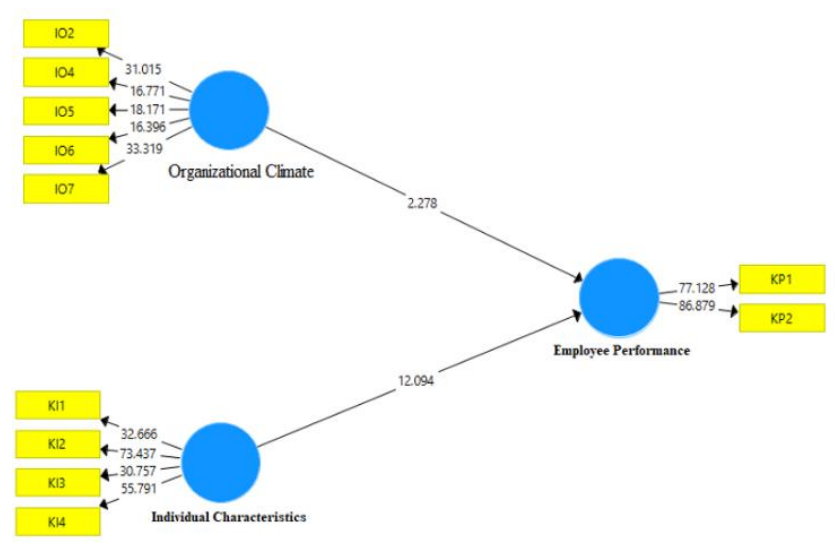

Figure 1. Hypothesis Testing Using Bootstrap 
Tabel 4. T Statistics Results

\begin{tabular}{|l|l|l|l|c|c|}
\hline \multicolumn{1}{|c|}{ Variable } & $\begin{array}{c}\text { Original } \\
\text { Sample }\end{array}$ & $\begin{array}{c}\text { Sample } \\
\text { Mean }\end{array}$ & $\begin{array}{c}\text { standard } \\
\text { deviation }\end{array}$ & $\begin{array}{c}\mathrm{T} \\
\text { Statistics }\end{array}$ & $\begin{array}{c}\mathrm{P} \\
\text { Value }\end{array}$ \\
\hline $\begin{array}{l}\text { Organizational Climate } \rightarrow \text { Employee } \\
\text { Performance }\end{array}$ & 0.153 & 0.155 & 0.067 & 2.278 & 0.023 \\
\hline $\begin{array}{l}\text { Individual Characteristics } \rightarrow \text { Employee } \\
\text { Performance }\end{array}$ & 0.715 & 0.715 & 0.059 & 12.094 & 0.000 \\
\hline
\end{tabular}

The results of multiple linear regression analysis on the $\mathrm{F}$ test (simultaneous test) show that organizational climate variables influence employee performance. This is known from the value of Fcount $\geq$ from the value of $F$ table (2,278 greater than 1.96). So that it can be said that the organizational climate can affect the level of performance of employees who work at BPJS Employment. In the partial test (t-test) it was found that organizational climate significantly affected the performance of employees with a p-value of 0.023 less than $0.05(\mathrm{p}=0.023<0.05)$. These results indicate that the organizational climate influences the performance of BPJS Employment employees.

The influence of organizational climate on employee performance can be illustrated from the results of research showing an average score of an organization's climate score of 829.33 which is included in the high category, the statement with the highest score is "I can communicate openly with colleagues" and "Attitudes of leaders/superiors affect employee productivity, "this shows every employee wants to have or get good cooperation between employees and superiors, so it has an impact on improving employee performance.

This is supported by research conducted by Risnawati (2017) which states that organizational climate influences employee performance, if the organizational climate gets stronger and increases it results in a conducive work atmosphere, Ahmad (2018) states that if the organizational climate gets stronger and increases it will produce conducive work atmosphere.

Individual Character also influences Employee Performance, this is shown from the results of multiple linear regression analysis in the $F$ test (simultaneous test) showing that the individual characteristic variables influence employee performance. This is known from the value of Fcount $\geq$ from the value of $F$ table $(12,094$ greater than 1.96). So it can be said that the Individual Character influences the level of performance of employees who work at BPJS Employment. In the partial test ( $t$ test), it was found that the individual character had a significant effect on employee performance with a $\mathrm{p}$ value of 0,000 less than 0.05 ( $p=0,000<0.05)$. The result is that the organizational climate influences the performance of BPJS Employment.

Individual characteristics of employee performance are getting higher on their work, and have needs that must be fulfilled then employees will have a strong drive to work hard so that their performance will also increase according to the results of research on the 
statement "my work is done responsibly", this makes employees do their work with responsibilities so it has implications for improving the performance of BPJS employment.

This is supported by Hidayat \& Cavorina's theory (2017), which says that individual characteristics variables significantly influence employee performance because if the company has good individual characteristics, this will create a good performance for employees.

The influence of organizational climate and individual character on employee performance shows a close relationship (R2) of 0.677 , meaning that $67.7 \%$ of employee performance is influenced by organizational climate and individual character variables and $33.3 \%$ is influenced by other variables.

\section{CONCLUSION}

1. Organizational Climate, Individual Character and Employee Performance of the Sulawesi Maluku Regional Office and its Alignment are classified as good in the "good" category, this is indicated by the average score above 800 in the high category.

2. Organizational climate and individual characteristics are positively and significantly related to the performance of employees of the Sulawesi Maluku Regional Office and its Alignments.

\section{REFERENCES}

[1]. Astri Nadira. 2015. Pengaruh Karakteristik Individu dan Lingkungan Kerja terhadap Kinerja Karyawan Divisi Sumber Daya Manusia pada PT. Perkebunan Nusantara III Medan. Skripsi pada Fakultas Ekonomi dan Bisnis
Universitas Sumatera Utara, Medan: tidak diterbitkan

[2]. Burhanuddin, Afid. 2013. Landasan Teori, Kerangka Pikir, dan Hipotesis. Tersedia:https://afidburhanuddin.wordpress.co m/2013/05/21/landasan-teori-kerangka-pikirdan-hipotesis [22 Agustus 2015].

[3]. Creswell, John. 2012. Research Design: Pendekatan Kualitatif, Kuantitatif, dan Mixed. Yogyakarta: Pustaka Pelajar.

[4]. Fitra, Fitra. 2010. Analisis Jalur (Path Analysis) Tersedia:

https://www.academia.edu/3075526/analisis_jal ur [15 Agustus 2015].

[5]. Guilford, Joy. P., \& Fruchter, B. (1981). Fundamental Statistics In Psychology and Education (6th ed.). Singapore: McGraw Hill Book Company.

[6]. Hendry. 2015. Iklim Organisasi. Tersedia: https://teorionline.wordpress.com/category/ku mpulan-teori/iklim organisasi [23 Agustus 2015]

[7]. Ivancevich, J.Matteson dan Michael. T. 2006. Perilaku dan Manajemen Organisasi. Jakarta: Erlangga.

[8]. Liana, Lie. 2009. Penggunaan MRA dengan Spss untuk Menguji Pengaruh Variabel Moderating terhadap Hubungan antara Variabel Independen dan Variabel Dependen. Jurnal Teknologi Informasi DINAMIK Volume XIV (2): $\quad$ 90-97 ISSN:0854-9524. Tersedia: http://download.portalgaruda.org/article.php?ar ticle $=7441 \& v a l=544$ [10 Agustus 2015].

[9]. Lubis, Yusniar. 2012. Pengaruh Karakteristik Individu, Karakteristik Pekerjaan, Iklim Organisasi terhadap Kepuasan dan Kinerja Karyawan. Skrispi.

[10]. Normansyah. 2010. Analisis Pengaruh Karakteristik Individu dan Budaya Organisasi 
Terhadap Kinerja Pegawai di Universitas Asahan Kisaran. Skripsi.

[11]. Risnawati. 2017. Pengaruh Iklim Organisasi terhadap Kinerja Pegawai pada Kantor Wilayah Ditjen Perbendahaaraan Negara Provinsi Sulawesi Selatan. Skrispsi. Universitas Islam Negeri Alauddin Makassar.

[12]. Rivai, Veithzal. 2004, Manajemen Sumber Daya Manusia untuk Perusahaan, dari Teori ke Praktik, (Cetakan Pertama). Jakarta: PT. Raja Grafindo Persada.

[13]. Robbins, S. P. 2003. Organizational behavior. Upper Saddle River: Pearson Education

[14]. Robbins, Stephen P dan Timothy A. Judge. 2008. Perilaku Organisasi, Edisi Kedua Belas. Jakarta: Salemba Empat.

[15]. Umam, Ahmad. K. 2018. Pengaruh Iklim Organisasi terhadap Kinerja Pegawai Kantor Wilayah Kementerian Agama Provinsi Banten. Skripsi. Universitas Sultan Ageng Tirtayasa.

[16]. Santoso, Singgih. 2015. Menguasai SPSS 22. Jakarta: PT Elex Media Komputindo

[17]. Simamora, Henry. 2004. Manajemen Sumber Daya Manusia. Yogyakarta: SIE YKPN.

\section{Cite this article as :}

Muhammad Ardiansyah, Sri Setya Handayani, "The Influence of Climate Organization and Individual Characteristics on the Employees' Performance of Regional Office of Sulawesi, Maluku, and Its Alignments", International Journal of Scientific Research in Science and Technology (IJSRST), Online ISSN : 2395-602X, Print ISSN : 2395-6011, Volume 6 Issue 4, pp. 261-275, July-August 2019. Available at doi : https://doi.org/10.32628/IJSRST196445 Journal URL : http://ijsrst.com/IJSRST196445 